\title{
1-D Air-snowpack modeling of atmospheric nitrous acid at South Pole during ANTCI 2003
}

\author{
W. Liao and D. Tan \\ Georgia Institute of Technology, Earth and Atmospheric Sciences Department, 311 Ferst Dr. Atlanta, GA 30332, USA \\ Received: 26 February 2008 - Published in Atmos. Chem. Phys. Discuss.: 28 May 2008 \\ Revised: 27 August 2008 - Accepted: 28 October 2008 - Published: 6 December 2008
}

\begin{abstract}
A 1-D air-snowpack model of HONO has been developed and constrained by observed chemistry and meteorology data. The 1-D model includes molecular diffusion and mechanical dispersion, windpumping in snow, gas phase to quasi-liquid layer phase HONO transfer and quasi-liquid layer nitrate and interstitial air HONO photolysis. Photolysis of nitrate is important as a dominant HONO source inside the snowpack, however, the observed HONO emission from the snowpack was triggered mainly by the equilibrium between quasi liquid layer nitrite and firn air HONO deep down the snow surface (i.e. $30 \mathrm{~cm}$ below snow surface). The high concentration of HONO in the firn air is subsequently transported above the snowpack by diffusion and windpumping. The model uncertainties come mainly from lack of measurements and the interpretation of the QLL properties based on the bulk snow measurements. One critical factor is the ionic strength of QLL nitrite, which is estimated here by the bulk snow $\mathrm{pH}$, nitrite concentration, and QLL to bulk snow volume ratio.
\end{abstract}

\section{Introduction}

Increasing interest has been focused on the measurement of atmospheric nitrous acid (HONO) in the high latitude boundary layer. HONO plays an important role in the atmosphere due to its photo-dissociation by UV radiation into hydroxyl $(\mathrm{OH})$ and nitric oxide $(\mathrm{NO})$ radicals. As a result of poor vertical mixing in the polar lower atmosphere, snow pack emissions of HONO remain confined to a thin layer near the surface, where $\mathrm{HONO}$ can give rise to a much greater production of $\mathrm{OH}$ radicals in Arctic polar sunrise than previously believed (Domine and Shepson, 2002). A number of measurements (Table 1) report elevated HONO concentrations,

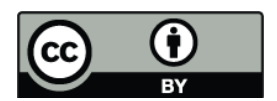

Correspondence to: D. Tan (dtan@eas.gatech.edu) sometimes much higher than can be accounted for in photochemistry models. The high levels of HONO reported often lead to a dramatic over-prediction of $\mathrm{HO}_{\mathrm{x}}$ (Davis et al., 2004) and sometimes $\mathrm{NO}_{\mathrm{x}}$ (Dibb et al., 2004), because these high levels are difficult to reconcile with concurrent measurements of $\mathrm{OH}, \mathrm{HO}_{2}$ and $\mathrm{NO}$. These results raised possible missing sinks for $\mathrm{HO}_{\mathrm{x}}$ and $\mathrm{NO}_{\mathrm{x}}$ or, alternatively, problems with the HONO measurements.

The Antarctic Troposphere Chemistry Investigation (ANTCI) is a four-year program including two major field studies (2003 and 2005) in Antarctica. The major science objectives are to evaluate the physical and chemical processes of nitrogen oxides and hydrogen oxides; to compare boundary layer measurements of South Pole with other regions of Antarctica; and to investigate the importance and location of the coast-to-plateau transport of sulfur. Measurements during ANTCI 2003 at the Amundsen-Scott South Pole Station include $\mathrm{OH}, \mathrm{HO}_{2}, \mathrm{H}_{2} \mathrm{SO}_{4}, \mathrm{HONO}, \mathrm{HO}_{2} \mathrm{NO}_{2}, \mathrm{SO}_{2}, \mathrm{HNO}_{3}$, $\mathrm{NO}, \mathrm{NO}_{\mathrm{y}}, \mathrm{O}_{3}, \mathrm{PAN}, \mathrm{H}_{2} \mathrm{O}_{2}, \mathrm{HCHO}$, non-methane hydrocarbons, halocarbons, $\mathrm{CH}_{4}, \mathrm{CO}$, DMS, aerosol chemical composition, $\mathrm{Hg}$, temperature, relative humidity, wind speed, wind direction, boundary layer height and actinic fluxes.

The gas phase HONO mixing ratios are measured by mist chamber/ion chromatography (MC/IC) and laser-induced fluorescence (LIF) techniques. MC/IC observations were higher than the LIF observations by a factor of $7.2 \pm 2.3$ in the median. Both measurement results are significantly higher than what a pure gas model can predict (Liao et al., 2006). Quantifying the amount of HONO emitted by snowpack is important for the photochemistry budget, especially the $\mathrm{HO}_{\mathrm{x}}$ budget. Furthermore, a deeper understanding of the heterogeneous processes involving snowpack important to HONO is also necessary to account for additional source/sink of HONO. Consequently, the main goal of this paper is the quantitative assurance of these elevated daytime HONO mixing ratios, which are used to evaluate the importance of $\mathrm{HONO}$ with respect to $\mathrm{HO}_{\mathrm{x}}$ and the possible magnitude of snow emission of HONO.

Published by Copernicus Publications on behalf of the European Geosciences Union. 
Table 1. Summary of measured HONO at Polar Regions.

\begin{tabular}{lcrl}
\hline Time and Place & HONO(pptv) & Height & Reference \\
\hline 2-4 July 1999 Summit & 10 & $75 \mathrm{~cm}$ & Dibb et al. (2002) \\
27-28 June 2000 Summit & 15 & $2 \mathrm{~m}$ & Honrath et al. (2002) \\
1992 April Alert & $5-10$ & $5 \mathrm{~m}$ & Li (1994) \\
2000 April noon Alert & 10 & $5 \mathrm{~m}$ & Zhou et al. (2001) \\
27 December 2000 South Pole & 25 & $10 \mathrm{~m}$ & Dibb et al. (2004) \\
27 December 2000 South Pole & 5-71, average 30, median 33 & $85 \mathrm{~cm}$ & Dibb et al. (2004) \\
December 2003 South Pole & median 7.2 2.3 & $10 \mathrm{~m}$ & Liao et al. (2006) \\
\hline
\end{tabular}

\section{Model descriptions}

\subsection{Overview of the snowpack model}

Current research in polar snow chemistry focuses on the chemical and physical transfer processes that control the concentrations and fluxes of the atmospheric components. Understanding the transfer processes is essential to snow chemistry. To the best of the authors' knowledge, models for investigating snow chemistry to date only include hydrogen peroxide by McConnell et al. (1998) and formaldehyde by Hutterli et al. (1999). They use parameterizations to relate gas concentrations in the ice to those in the firn air (Domine et al., 2007).

A series of field campaigns (e.g. Greenland, Honrath et al., 1999, 2002; ISCAT, Davis et al., 2004; CHABLIS, Jones et al., 2007, etc.) in polar regions have spurred intense interest in the photochemistry occurring in snow. Because snow has a large surface-to-volume ratio, it can efficiently remove atmospheric trace gases from the gas phase by adsorption, thus modifying atmospheric composition. Adsorbed gases can release reactive trace gases back to the interstitial air via heterogeneous photochemistry. Changes in wind speed and wind direction may affect snowpack ventilation and therefore interstitial air species may come out of the snowpack via diffusion and windpumping processes.

The boundary layer is ubiquitously stable in the polar region, due to the combined effects of the infra-red properties and albedo of the snow and low sun angle (Anderson and Neff, 2007). The lack of diurnal radiation variations during ANTCI 2003 makes the stable boundary layer condition with suppressed vertical mixing more obvious at South Pole than at other polar locations (Helmig et al., 2007). This causes snowpack emissions at South Pole to accumulate to higher mixing ratios than other polar sites.

Photochemical production of HONO has been reported as products of nitrate photolysis in natural and artificial snow (Honrath et al., 1999, 2000). Sampling of HONO $30 \mathrm{~cm}$ below the snow surface found levels much higher than at $10 \mathrm{~cm}$ below the snow surface (Jacobi et al., 2004). Photolysis of nitrate alone cannot explain the measured high concentration of ambient HONO because there is hardly any actinic flux $30 \mathrm{~cm}$ deep in the snow. We assume that the $\mathrm{NO}_{2}^{-}$in the quasi-liquid layer is the source of snowpack emission of HONO:

$\mathrm{NO}_{2(\mathrm{aq})}^{-}+\mathrm{H}_{(\mathrm{aq})}^{+} \rightleftharpoons \mathrm{HONO}_{(\mathrm{aq})} \stackrel{\text { Henry's Law }}{\longleftrightarrow} \mathrm{HONO}_{(\mathrm{gas})}$

$\mathrm{NO}_{2}^{-}$is protonated to produce $\mathrm{HONO}$ which will be released into the gas phase. The HONO has a long lifetime deep below the snow surface so that the equilibrium between quasiliquid nitrite and interstitial air HONO according to Henry's law is reached. This high interstitial air HONO is transported to the surface snow by wind pumping and subsequent diffusion to the ambient air. During this transport process, HONO concentrations are reduced by photolysis and uptake on ice. In this way, the HONO concentration is greater deep into the snowpack and its concentration is proportional to snowpack nitrite concentration, which in turn is very sensitive to the acidity of the snowpack. Photolysis of nitrate as well as $\mathrm{NO}_{2}$ hydrolysis could serve as the source of nitrite. Modeling of the nitrite and nitrate in the quasi-liquid layer is beyond the scope of this paper. We assume constant vertical profiles of nitrate and nitrite concentration in the absence of profile measurements. We build a comprehensive 1-D model to quantify the above mentioned processes.

The model is comprised of wind pumping, diffusion, chemistry, and inter-phase transfer processes. First we present the master equation describing the physical and chemical processes being modeled. Then we explain the wind pumping and actinic flux inside the snowpack. We further discuss chemical sources and sinks and quasi liquid layer nitrite partitioning to explain the observed high HONO concentrations above the snow surface and how this high concentration HONO is ventilated throughout the snowpack. In the end, we briefly discuss the factors important to quantifying snowpack HONO emission. The model is highly constrained by available measurement data including 
dimensions of sastrugi, snow surface actinic flux, bulk snow $\mathrm{pH}$, bulk snow $\left[\mathrm{NO}_{3}^{-}\right]$, bulk snow $\left[\mathrm{NO}_{2}^{-}\right]$, surface momentum flux, and temperature.

\subsection{Master equation}

The quasi-liquid layer (QLL) is a disordered layer of ice at the surface that has chemical properties closer to liquid water than solid crystalline ice (Boxe, 2005). Ionic solutes are efficiently excluded from the ice matrix upon freezing, and in the presence of solutes it is not clear whether the surface layer of ice is a true liquid or a quasi-liquid. There are no reaction data for the QLL phase reactions or for the thickness of the QLL as a function of temperature for solute-containing ices. The model assumes that the surface layer is a true liquid with a significant freezing point depression and uses the known aqueous phase reactions. Henceforth we will refer to this layer as the surface layer or the "QLL" to distinguish it from the true QLL that forms on pure water ices. The volume exclusion factor, that is, the surface layer thickness relative to the snow grain radius, is very important to scaling the bulk snow solute concentration to the "QLL" solute concentration.

Diffusion and ventilation are two important processes that affect the movement of trace gases within a snowpack. Diffusion is a transport process driven by both concentration and temperature gradients, whereas wind ventilation provides an advective transport process by interstitial air movement within the snowpack. Trace gas concentrations are also affected by in situ chemistry production/loss and gas/liquid exchange. We model interstitial HONO using the combination of one-dimensional advection-dispersion equation by McConnell et al. (1998) and multiphase model by Sportisse and Djouad (2000):

$$
\begin{aligned}
\frac{\partial C_{g}}{\partial t} & =D \frac{\partial^{2} C_{g}}{\partial z^{2}}-U \frac{\partial C_{g}}{\partial z} \\
& +Q_{g}-S_{g}-3 \frac{\lambda_{m}}{a} \cdot \frac{L W C}{1-L W C} \\
& \cdot\left(C_{g}-\frac{C_{a} \cdot P}{H} \cdot 10^{12}\right)
\end{aligned}
$$

where $C_{g} / C_{a}$ is the gas/liquid phase HONO concentration, $t$ and $z$ are time and depth, respectively. The first two terms describe transport of gas phase HONO by dispersion and convection. $D$ is the dispersion, including both gas-phase molecular diffusion $D_{g}$ and mechanical dispersion $D_{m}$. The mechanical dispersion is caused by advective mixing of tracers on the pore scale and is given by the product of the absolute value of the flow velocity field $v$ and a dispersion length (generally taken as the mean pore diameter) $d$ (Neuweiler et al., 2001). Under South Pole conditions, $d$ is $2 \mathrm{~mm}$ (Waldner et al., 2004), the daily average pore velocities range from $10^{-2}$ to $10^{-4} \mathrm{~m} / \mathrm{s}$. $D_{g}$ is $1.4 \times 10^{-5} \mathrm{~m}^{2} / \mathrm{s}$ (Reid et al., 1987 ; Ervens et al., 2003). $U$ is the wind pumping velocity of the air in the $z$ direction. Please see Sect. 2.3 for details of wind pumping .

$Q$ and $S$ represent the chemical sources and sinks for gas phase HONO within the snowpack. Here we assume that $\mathrm{HONO}$ photolysis is the most important sink and $\mathrm{NO}_{3}^{-}$ photolysis is the most important source. Snowpack nitrate profiles were not measured, so the concentration of $\mathrm{NO}_{3}^{-}$is assumed to be constant with snow depth, which is $\mathrm{NO}_{3}^{-}=2 \cdot 10^{-5} \mathrm{~mol} / \mathrm{kg}$ (J. Dibb, personal communication, 2006). The photolysis rates of nitrate have similar profiles with depth through out the modeling period. We use the quantum yield for HONO formation by nitrate photolysis of $(3.8 \pm 0.6) \times 10^{-4}$ (Bartels-Rausch and Donaldson, 2006). The actinic flux calculation inside the snowpack is in Sect. 2.4. Snow pit measurements by the University of New Hampshire (Dibb, personal communication) show that bulk nitrite concentrations are four orders of magnitude less than that of nitrate. It is not feasible to model snow-phase nitrite for ANTCI 2003, given the lack of profiles and the limited chemical measurements in the snowpack: here we use the UNH bulk nitrite and assume a constant concentration of nitrite with snow depth.

The transfer of molecules from the interstitial air to the "QLL" and vice versa is treated by the last term in Eq. (3). The net flux is the difference of the departure from Henry's law equilibrium at the surface and the reactive uptake of HONO on the snow surface. Trace gases can diffuse to the "QLL" or collide and stick to the surface of "QLL". In the case of HONO, the mass transfer is controlled mainly by the interfacial mass transport term (Schwartz, 1986). Mass accommodation coefficient and reversible dissolution according to the Henry's Law are taken into account. LWC is the unitless liquid water content:

$\mathrm{LWC}=\frac{\rho_{\text {firn }}}{\rho_{\text {ice }}} \cdot \mathrm{QLL}$ to snow volume ratio $=$

$0.47 \times 2 \times 10^{-3}=9.4 \times 10^{-4} \mathrm{vol} / \mathrm{vol}$.

$\lambda_{m}$ describes the mass transfer through the gas-liquid phase:

$\lambda_{m}=\frac{1}{4} \alpha \bar{v}$

The QLL to snow volume ratio is taken from Michalowski, et al (2000). $\alpha$ is the mass accommodation coefficient and we use the value 0.1 (Sportisse and Djouad, 2000); $\bar{v}$ is the mean molecular velocity; $a$ is the snow grain radius $(1 \mathrm{~mm})$. $H$ stands for the Henry law constant (Park and Lee, 1988) and $P$ is the pressure. The factor $10^{12}$ in Eq. (2) is used to scale to the gas phase concentration in units of part per trillion (ppt).

The solar zenith angle during ANTCI 2003 is near constant and the constrained input data points are ten minute averages. It is reasonable to assume quasi-steady state conditions for gas phase concentrations, that is $\frac{\partial C}{\partial t}=0$. Essentially the assumption is that HONO neither builds up nor depletes in the time period of the model. This is of course insupportable at polar dawn and dusk, and may not apply for transient events during the modeling period (just as it would not apply for high solar zenith angle and transient events in any 


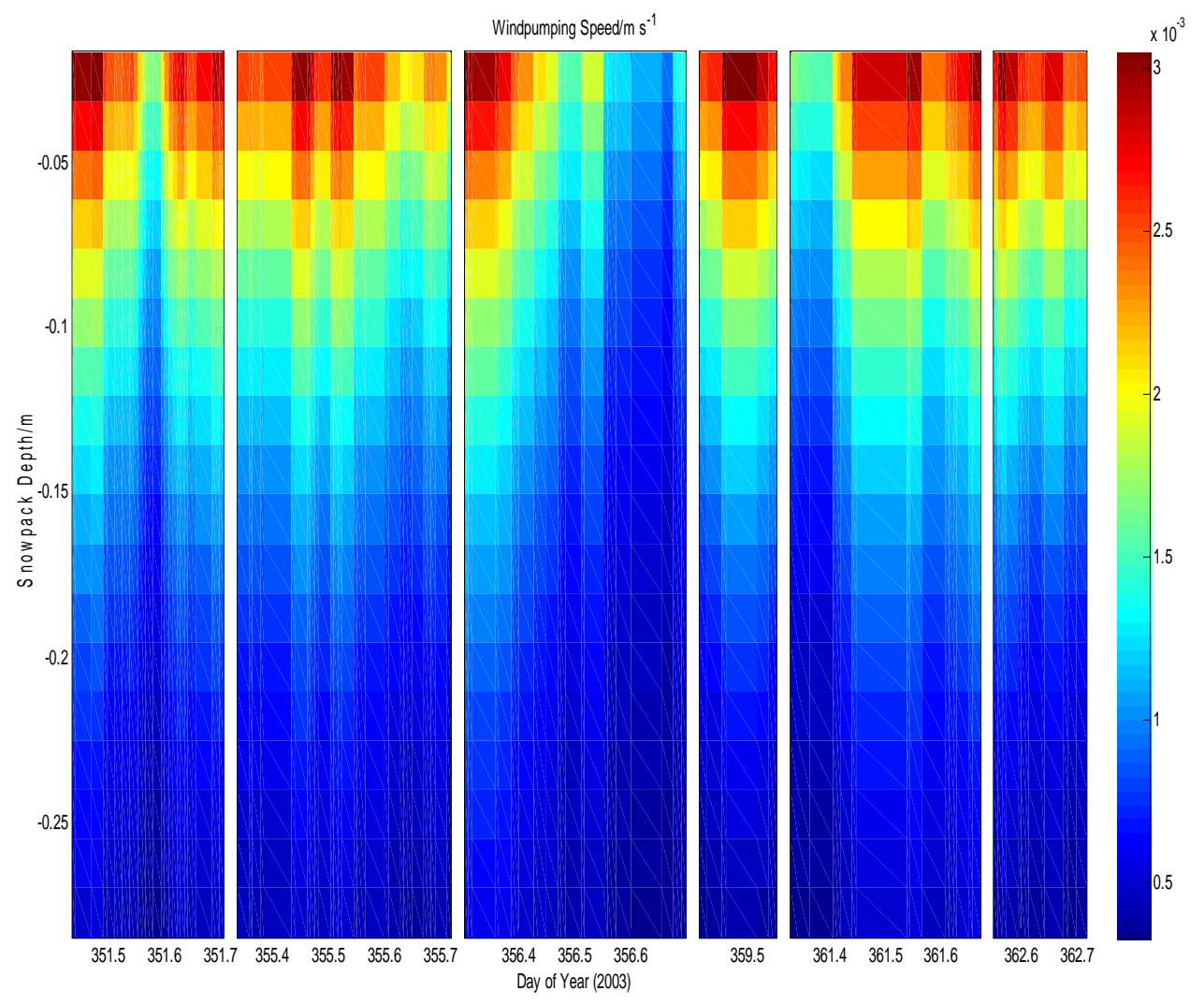

Fig. 1. Simulation of wind pumping speed from $0 \mathrm{~m}$ to $0.3 \mathrm{~m}$ below snow on 17, 21, 22, 25, 27 and 28 December.

steady state photochemical model). While it is a simplifying assumption, it is harder to justify a buildup or depletion of HONO when conditions are not changing rapidly, as was the case for most of ANTCI 2003. Equation (3) then reduces to an ordinary differential equation. We set the HONO concentrations to be five pptv at the snow surface and at the bottom to be $160 \mathrm{pptv}$ and linearly interpolate the intermediate layer concentrations for the initial conditions. There is no constraint for the upper and lower boundary and they are solved numerically (Matlab, Natick, MA) for the top $30 \mathrm{~cm}$ of the snowpack, using 20 uniformly distributed layers for a vertical resolution of $1.5 \mathrm{~cm}$. The vertical profiles of HONO concentrations are robust to the choice of initial conditions. Wind pumping (Sect. 2.3), diffusion and actinic flux (Sect. 2.4) are calculated within the snow pack.

\subsection{Wind pumping}

Waddington et al. (1996) estimated that the surface area of ice grains in the upper $7 \mathrm{~cm}$ was more than three orders of magnitude larger than the area of a smooth impenetrable surface. Therefore the snow surface may be considered to be a big chemical reaction chamber. The transfer of local chemical tracers into the snow or vice versa by air flow through the snow (wind pumping) is important for snow chemistry. Snow contains varying quantities of air, the large part of this air volume will be replaced frequently due to changes of air pressure and strong winds above the surface. The snow structure and surface roughness will determine the ventilation processes.

Sastrugi are meter-scale longitudinal dunes eroded by the wind. Sastrugi are most prominent where ice-sheet surfaces are exposed to persistent strong winds from a single direction, as on the perimeter of East Antarctica. At the South Pole, the winds are weaker and more variable, and the lengths of sastrugi are typically a few meters, widths $1 \mathrm{~m}$, and heights $0.1-0.5 \mathrm{~m}$. Sometimes there are two or three sets of sastrugi crossing each other and forming a network of ridges (Warren et al., 1998).

Air pressure should be elevated over some area on the upwind face of a topographic bump due to dynamic wind pressure, and should be lowered over some area on the lee side near the crest of the bump due to the airfoil effect associated with the increased velocity. The pressure differences on the surface would induce pressure gradients and steady air flow within the bump and surrounding snow. Toyota and McConnell (2005) derived the mean 1-D wind pumping speed for the Darcy's flow rate within the snowpack. 


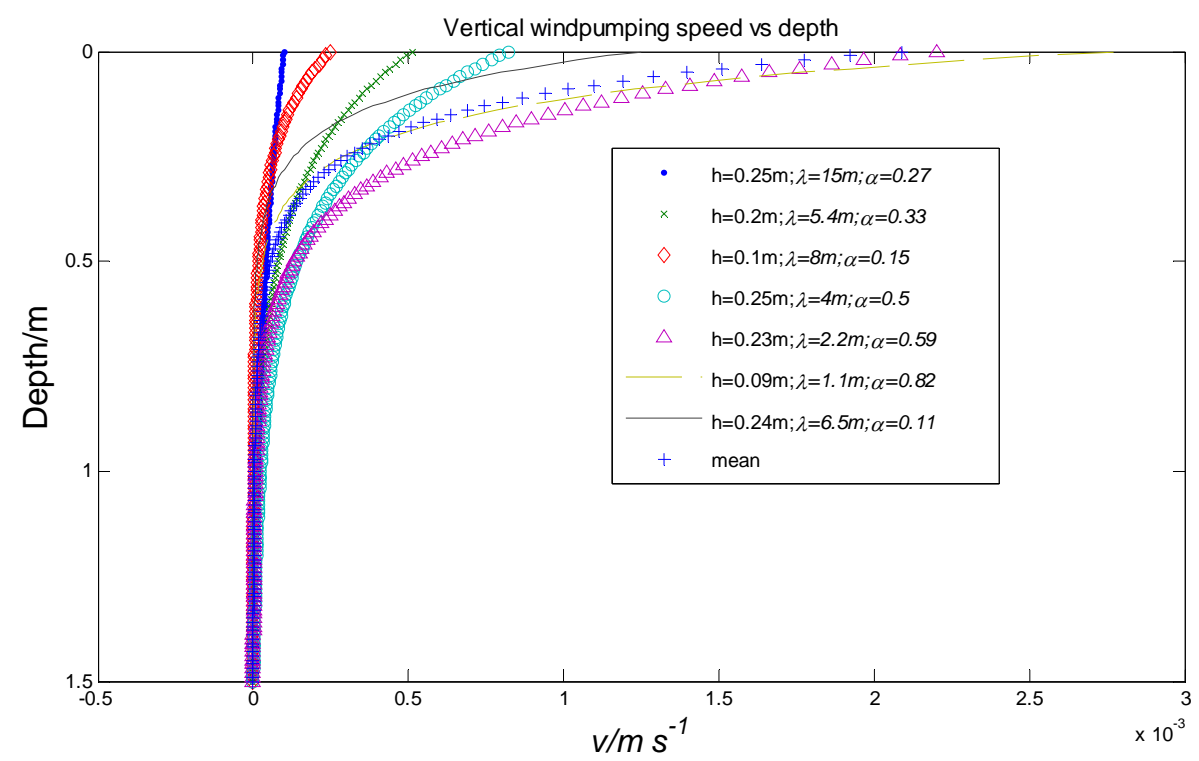

Fig. 2. Simulation of wind pumping speed based on different dimensions (Table 2) of summertime sastrugi at South Pole. $h$ : relief amplitude; $\lambda$ : relief wavelength; $\alpha$ : horizontal aspect ratio of reliefs. The surface wind speed is $5.1 \mathrm{~m} / \mathrm{s}$. The smaller surface features generate stronger flows. The e folding depth for the mean speed is $10 \mathrm{~cm}$.

Toyota and McConnell did extensive model testing and found that their 1-D windpumping model is almost equivalent to 2-D advection averaged over the whole wavelength of microtopography when they work with discrete equations for numerical integration:

$U=\frac{k}{\mu} \frac{6 \rho_{\mathrm{air}} u^{2}}{\pi} \frac{h}{\lambda} \frac{1}{\lambda} \frac{\sqrt{\alpha^{2}+1}}{\alpha}\left(C_{1} \exp \left(-\frac{z}{\delta}\right)-C_{2} \exp \left(\frac{z}{\delta}\right)\right)$

where

$\delta=\frac{\alpha}{\sqrt{\alpha^{2}+1}} \frac{\lambda}{2 \pi}$, which is the e-folding depth Eq. (5)

$C_{1}=\frac{\exp \left(\frac{H_{s}}{\delta}\right)}{\exp \left(\frac{H_{s}}{\delta}\right)+\exp \left(-\frac{H_{s}}{\delta}\right)}$

$C_{2}=\frac{\exp \left(-\frac{H_{s}}{\delta}\right)}{\exp \left(\frac{H_{s}}{\delta}\right)+\exp \left(-\frac{H_{s}}{\delta}\right)}$

$U$ : Wind pumping speed; $k$ : permeability; $\mu$ : dynamic viscosity of air; $u$ : surface wind speed, measured at $2 \mathrm{~m}$ above snow surface; $\rho_{\text {air }}$ : air density; $h$ : relief amplitude; $\lambda$ : relief wavelength; $\alpha$ : horizontal aspect ratio of relief which is the horizontal axe divided by the relief wavelength. If $\alpha<1$ then the relief is elongated in the wind direction like sastrugi; $z$ : distance from the atmosphere-snowpack interface; $H_{s}$ : mean snow depth $(15 \mathrm{~cm})$;

We applied their windpumping model under conditions relevant to the South Pole during ANTCI 2003. There are no sastrugi measurements from ANTCI 2003. Here the 1994
South Pole summertime measurement data are used (Table 2) (Warren et al., 1998). We call each representative shape a feature. The weighting function is assumed to be inversely proportional to the sastrugi's area (S. Warren, personal communication, 2006). We multiply each wind pumping speed with the respective weighting function and add them together to get the mean wind pumping speed (Fig. 1).

The largest uncertainties of wind pumping arise from the parameterization of the snow microtopography and from the permeability of the near-surface snow (Cunningham and Waddington, 1993). For example, the windpumping speed based on the sastrugi feature 6 in Table 2 is twenty times of that based on feature 1 near the surface, and the difference decreases exponentially with depth (Fig. 2).

\subsection{Actinic flux inside the snowpack}

The snowpack is modeled as a diffusive medium with actinic flux circulating through it. A two-stream method was used for the movement (Toon et al., 1989). Actinic flux is divided into an upward and downward component. Each of the components is approximated with a forward and backward probability function. Scattering by snow grains has a forward diffraction peak, making two-stream expansion of the probability function inadequate. To correct this, a Delta-Eddington algorithm (Joseph et al., 1976) is used, which uses a delta function in the forward direction and a smooth scaled probability function. The optical properties of the snowpack are described by scattering and impurity absorption cross sections, as well as the snowpack density. Empirical values for absorption and scattering coefficients are parameterized 
Table 2. Dimensions of typical of summertime sastrugi at South Pole.

\begin{tabular}{ccccc}
\hline Feature & Height, $\mathrm{m}$ & Length, $\mathrm{m}$ & Width, $\mathrm{m}$ & Weighting Function, \% \\
\hline 1 & 0.25 & 15.0 & 4.0 & 0.9 \\
2 & 0.20 & 5.4 & 1.8 & 5.3 \\
3 & 0.10 & 8.0 & 1.2 & 5.4 \\
4 & 0.25 & 4.0 & 2.0 & 6.5 \\
5 & 0.23 & 2.2 & 1.3 & 18.1 \\
6 & 0.09 & 1.1 & 0.9 & 52.4 \\
7 & 0.24 & 6.5 & 0.7 & 11.4 \\
\hline
\end{tabular}

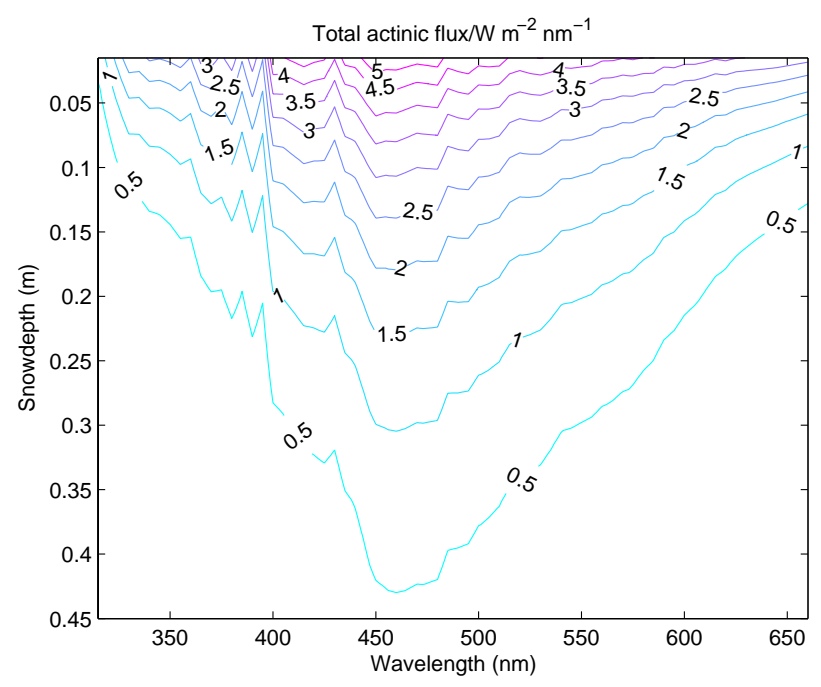

Fig. 3. Simulation of actinic flux with snow depth and wavelength. Conditions are: mass-specific scattering coefficient $\sigma_{\text {scatt }}=22.5 \mathrm{~m}^{2} \mathrm{~kg}^{-1}$, snow density $\rho=0.3 \mathrm{~g} \mathrm{~cm}^{-3}$, solar zenith angle $\theta=68^{\circ}$, no soot.

to match the existing observation data at polar regions so that no knowledge of the snow crystal size or shape is required (Lee-Taylor and Madronich, 2002). The diffusion equation was solved numerically by defined boundary conditions. The snow top boundary condition is derived from the Tropospheric Ultraviolet Visible (TUV) model (Madronich and Flocke, 1998). The TUV model is used to parameterize the atmospheric conditions on a cloudless day (21 December 2003). Cloud optical density and $\mathrm{O}_{3}$ and $\mathrm{NO}_{2}$ columns are chosen so that the values of $\mathrm{J}\left(\mathrm{O}^{1} \mathrm{D}\right)$ and $\mathrm{J}\left(\mathrm{NO}_{2}\right)$ from the model output match those derived by the Biospherical Company using an Eppley radiometer during ANTCI 2003. We scale every data point based on $\mathrm{J}\left(\mathrm{NO}_{2}\right)$ and $\mathrm{J}\left(\mathrm{O}^{1} \mathrm{D}\right)$ for that data point, which reflects the changing optical depth above the snow surface. For the bottom layer of the snow, the upward flux is zero.
The photolysis frequency, $J$, is determined for species $x$, by evaluating the following convolution product over all wavelengths:

$$
J_{x}=\int \sigma_{x}(\lambda) \Phi_{x}(\lambda) F(\lambda) d \lambda
$$

Here, $F(\lambda)$ is the spectral actinic flux (radiant flux density incident onto a spherical area) and $\sigma(\lambda)$ and $\Phi(\lambda)$ are, respectively, the absorption cross-section and the photodissociation quantum yield of the molecule $x$ at wavelength lambda from the TUV model (Madronich and Flocke, 1998). The absorption spectra and temperature-dependent quantum yield of nitrate are taken from Burley and Johnston (1992), Chu and Anastasio (2003), Warneck and Wurzinger (1988), Zellner et al. (1990) and Bartels-Rausch and Donaldson (2006). The efolding depths for $\mathrm{J}\left(\mathrm{NO}_{3}^{-}\right)$and $\mathrm{J}(\mathrm{HONO})$ are $6 \mathrm{~cm}$ and $8 \mathrm{~cm}$, respectively.

Figure 3 shows the total actinic flux changing with snowpack and wavelength. The total actinic flux peaks around $450 \mathrm{~nm}$ because the snow/ice has minimum absorption at this wavelength (Grenfell and Perovich, 1986; Perovich and Govoni, 1991). The structure between $300 \mathrm{~nm}$ and $400 \mathrm{~nm}$ is inherited from the incoming actinic flux at the snow surface.

\section{Results and discussion}

\subsection{Model results}

The wind pumping speed and actinic flux decrease sharply with depth. Deep below the snowpack surface, chemical reaction rates are slow enough that the gas phase HONO reaches equilibrium with the "QLL" phase HONO according to Henry's Law. Due to the lack of a measured nitrite profile, here we use a constant snowpack nitrite concentration. The bulk snow nitrite concentration, the median value of measured snowpack $\mathrm{pH}$ and "QLL" volume ratio were used to estimate the aqueous phase HONO concentration. Deep below the snow surface, we assume no vertical gradient $\left(\frac{\partial C_{g}}{\partial z}=0\right)$ and below the photic zone Eq. (3) simplifies to exactly the form of the Henry's Law. Assuming a bulk nitrite concentration of $20 \mathrm{nM}$ and a "QLL" volume exclusion factor of $10^{-3}$, the interstitial air HONO mixing ratio deep in the snowpack is estimated to be about 164 pptv.

Figure 4 shows the modeled HONO vertical profile inside the snowpack on 17, 21, 22, 25, 27 and 28 December. HONO distributions are primarily controlled by windpumping, and concentrations decrease significantly on 17, 25, 27 and 28 December when the boundary layer is high and the chemical migration is large due to advective transport (Fig, 5). On 21 and 22 December, the mean boundary layer depth is only $25.55 \mathrm{~m}$ and the atmosphere is very stable, in the low-wind scenario the migration of HONO in the snowpack can be largely attributed to diffusive transport. The windpumping drives the distribution of HONO in the snowpack. Turning 


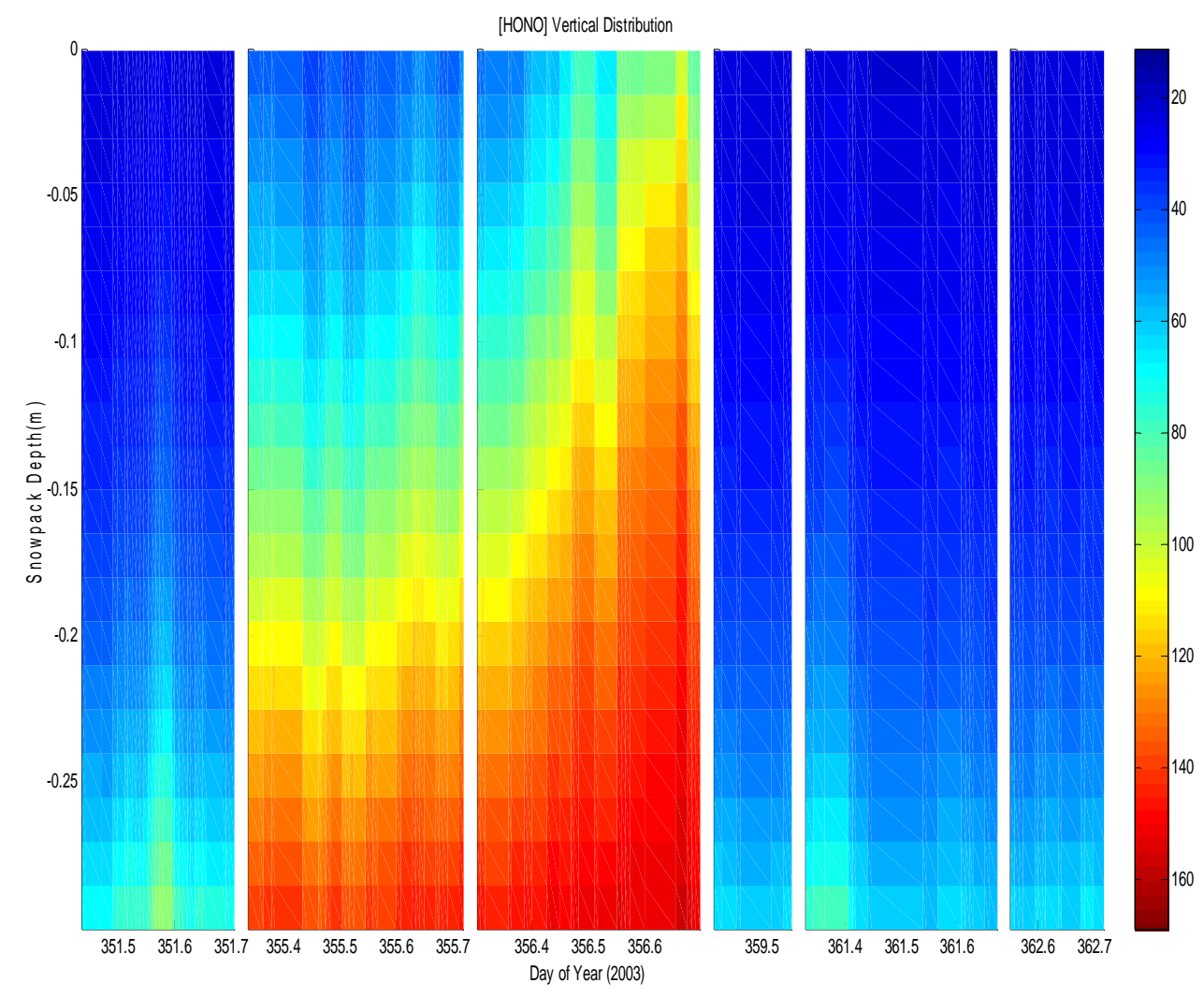

Fig. 4. Simulation of vertical profile of interstitial air HONO mixing ratio (pptv) inside the snowpack on 17, 21, 22, 25, 27 and 28 December.

this off leads to a mostly uniform distribution with respect to time, as the remaining dispersion/diffusion term is larger than the net chemical term, which ultimately derive from $\mathrm{J}\left(\mathrm{NO}_{3}^{-}\right)$ and $\mathrm{J}(\mathrm{HONO})$. In the absence of wind pumping the depth profile resembles the shallow boundary layer condition.

We compare the mean rate of nitrate photolysis to the required rate of $\mathrm{NO}_{2}^{-}$supply in each layer of the snowpack in order to balance the loss of HONO to the air in Fig. 6. We use a quantum yield of $(1.1 \pm 0.1) \times 10^{-3}$ for the photolysis of nitrate to nitrite channel (Warneck and Wurzinger, 1988). It is evident that nitrate photolysis alone is not sufficient to sustain the nitrite loss to HONO even at the surface, and that the contribution of nitrate photolysis decreases with depth. This indicates that "dark" sources of nitrite such as $\mathrm{NO}_{2}$ hydrolysis or possibly nitrate reduction by organics are significant, and dominate deeper in the snowpack. There is an important caveat, however: the model uses bulk values for nitrate and nitrite. The actual contribution from nitrate photolysis to nitrite may differ substantially from the model results if the actual nitrate depth profile is significantly different from that assumed, at least in the top $\sim 10 \mathrm{~cm}$ of snowpack, although the actual profile would have to be quite different from the model profile to have a significant effect on HONO concentrations (see below).

\subsection{Model sensitivity analysis}

Nitrous acid (HONO) and the nitrite ion represent a particularly important conjugate pair in the surface layer of ice. In highly acidic media, HONO will form nitroacidium ion, $\mathrm{H}_{2} \mathrm{ONO}^{+}$:

$\mathrm{H}_{2} \mathrm{ONO}_{(\mathrm{aq})}^{+} \stackrel{\mathrm{H}^{+}}{\longleftrightarrow} \mathrm{HONO}_{(\mathrm{aq})} \stackrel{\mathrm{H}^{+}}{\longleftrightarrow} \mathrm{NO}_{2(\mathrm{aq})}^{-}$

$\mathrm{pK}_{a 1}=1.7, \mathrm{pK}_{a 2}=2.8$ (Riordan, et al., 2005).

$$
\mathrm{HONO}_{(\mathrm{aq})}=\mathrm{N}(\mathrm{III}) \frac{\mathrm{K}_{\mathrm{a} 1}\left[\mathrm{H}^{+}\right]}{\left[\mathrm{H}^{+}\right]^{2}+\mathrm{K}_{\mathrm{a} 1}\left[\mathrm{H}^{+}\right]+\mathrm{K}_{\mathrm{a} 1} \mathrm{~K}_{\mathrm{a} 2}}
$$

The HONO concentration is very sensitive to the $\mathrm{pH}$, "QLL" to snow volume ratio and nitrite concentration of the snowpack (Table 3). From the table we can infer no nitrous acid emission on alkaline snow surfaces, which is consistent with the field measurements of Beine et al. (2005).

We keep $\left[\mathrm{NO}_{3}^{-}\right]$constant throughout this paper. In reality, nitrate concentrations are likely to vary somewhat. In order to see the effect of including the variation of $\left[\mathrm{NO}_{3}^{-}\right]$with depth and time, we double the $\left[\mathrm{NO}_{3}^{-}\right]$in the model. We see a significant increase of the ratio of the gas phase source versus sink but a very limited effect for the HONO vertical distribution in the snowpack (Fig. 7). From this we conclude that snowpack HONO profiles are relatively insensitive to variability in the nitrate profile. 

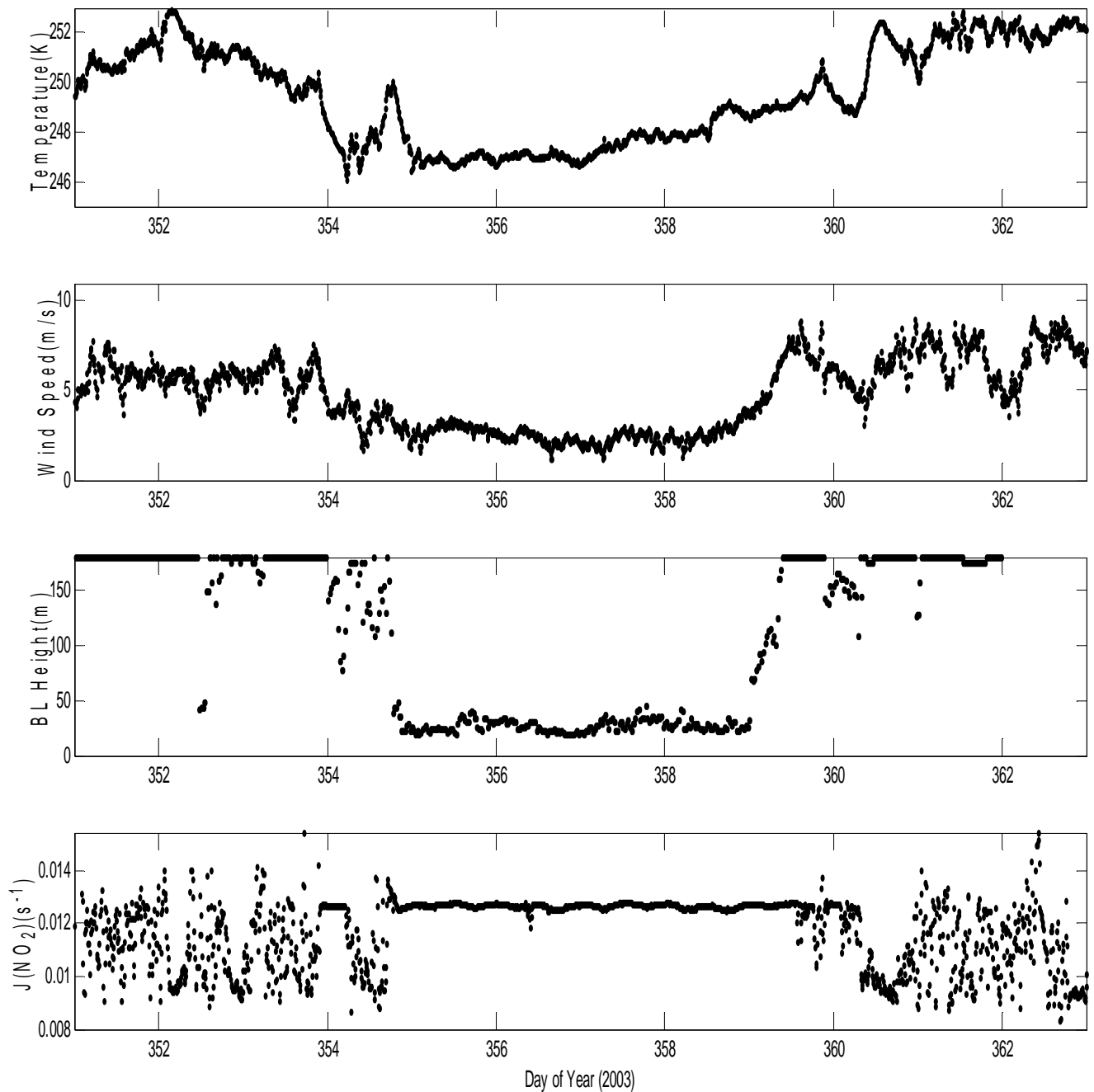

Fig. 5. Temperature, wind speed, boundary layer height and $\mathrm{J}\left(\mathrm{NO}_{2}\right)$ from 17 December to 28 December. They have the similar pattern in the sense that they decrease from 21 to 25 December when the mean boundary layer height is $26.7 \mathrm{~m}$.

Table 3. Sensitivity analysis of HONO concentration deep below snow surface where the equilibrium between QLL HONO and interstitial air $\mathrm{HONO}$ is reached. The $\mathrm{pH}$ and $\left[\mathrm{NO}_{2}^{-}\right]$are measured melted snow minimum, median, and maximum concentrations from 1 to 18 December 2003 (J. Dibb, personal communication). The bold numbers are the parameters used in the model.

\begin{tabular}{|c|c|c|c|c|c|c|c|c|c|}
\hline \multicolumn{5}{|c|}{ QLL to snow volume ratio $=2 \times 10^{-3}$} & \multicolumn{5}{|c|}{ QLL to snow volume ratio $=2 \times 10^{-4}$} \\
\hline \multirow{2}{*}{\multicolumn{2}{|c|}{ HONO (pptv) }} & \multicolumn{3}{|c|}{$\mathrm{pH}$} & \multirow{2}{*}{\multicolumn{2}{|c|}{ HONO (pptv) }} & \multicolumn{3}{|c|}{$\mathrm{pH}$} \\
\hline & & 5.3 & 5 & 4.5 & & & 5.3 & 5 & 4.5 \\
\hline \multirow[t]{3}{*}[\mathrm{NO}_{2}^{-}]{$\left(10^{-9} \mathrm{M}\right)$} & 1 & 4 & 8 & 24 & {$\left[\mathrm{NO}_{2}^{-}\right]\left(10^{-9} \mathrm{M}\right)$} & 1 & 42 & 82 & 235 \\
\hline & 20 & 84 & 164 & 470 & & 20 & 844 & 1644 & 4704 \\
\hline & 70 & 296 & 575 & 1646 & & 70 & 2955 & 5753 & 16463 \\
\hline
\end{tabular}




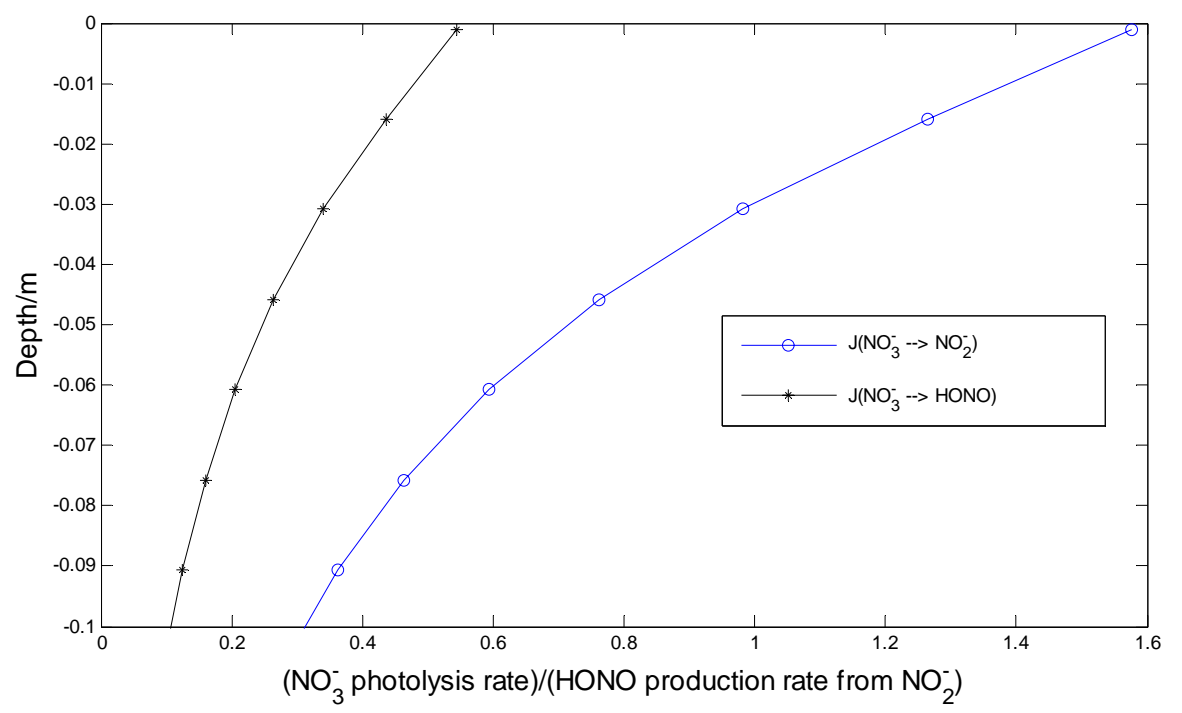

Fig. 6. Mean ratio of $\mathrm{NO}_{3}^{-}$photolysis rate versus the net $\mathrm{HONO}$ production rate from $\mathrm{NO}_{2}^{-}$in the top ten centimeters of the snowpack.

A major uncertainty is the "QLL" to snow volume ratio (the volume exclusion factor) which is likely to be strongly dependent on temperature. Here we have assumed a ratio of $10^{-3}$ : this is larger than the ratio for pure water ice because of the presence of solutes. The use of known liquid phase reaction mechanisms implicitly assumes that on freezing solutes are excluded to the surface of the ice, which develops a layer or possibly domains of highly concentrated liquid solution. That is, the surface layer is assumed to be a true liquid with high solute concentration, not a "quasi-liquid". This ratio is not known for naturally occurring ices, which are never pure. It is expected that the volume exclusion factor depends on total ionic strength as well as temperature. However, the nature of the surface of real-world ices is not known. This is a major model uncertainty. For instance, if the ratio is very low, such as is shown in the right panel of Table 3, we will need to revisit the relationship between surface volume layer and chemical concentration in this layer. If the thickness of "QLL" is very thin, it is unlikely that ions, such as $\mathrm{NO}_{3}^{-}$, will be solvated in this super-saturated solution in the quasi-liquid layer. In that case, some fraction of the ions will likely be excluded as crystals and we will need to estimate the saturation concentration for that temperature in the "QLL".

The volume exclusion factor also affects the liquid phase $\mathrm{pH}$. Aqueous phase HONO concentrations in the snowpack are very sensitive to acidity of the "QLL". It is assumed that ions are efficiently excluded on freezing, so the ratio of quasiliquid layer ion concentration to melted snow ion concentration inversely tracks the "QLL" volume ratio. If we can apply the assumption to $\mathrm{H}^{+}$, the $\mathrm{pH}$ of the "QLL" is likely to be significantly lower than that of the melted snow. In other words, the volume exclusion factor can influence the $\mathrm{pH}$ and further determine the ion distribution. However, how the $\mathrm{H}^{+}$ concentrations change on exclusion is not entirely clear because of possible buffer species in the "QLL". For example, the $\mathrm{CO}_{2}$ concentration at the South Pole is about $374 \mathrm{ppmv}$ (http://cdiac.ornl.gov/trends/co2/sio-spl.htm). $\left[\mathrm{HCO}_{3}^{-}\right]$is inferred to be $3.6 \cdot 10^{-5} \mathrm{M}$ in snow according to Henry's Law and the acid-base kinetics of carbonate ions. The melted snow $\mathrm{H}^{+}$concentration is $1.2 \cdot 10^{-5} \mathrm{M}$ (Dibb, personal communication). $\mathrm{HCO}_{3}^{-}$together with other ions could buffer the change of $\mathrm{H}^{+} . \mathrm{HCO}_{3}^{-}$is also an acid volatile (as are acids such as $\mathrm{HCl}$ ) and the freezing process and temperaturedriven fluctuations in the "QLL" thickness may force acid species with significant vapor pressures into the gas phase. In the "standard case" model run, it is supposed that the "QLL" $\mathrm{pH}$ remain constant at 5 and the "extra" $\mathrm{H}^{+}$is bound by other weak-acid anions or stays in the ice matrix. In contrast, $\mathrm{NO}_{2}^{-}$ and $\mathrm{NO}_{3}^{-}$stay within the surface layer completely. Figure 8 shows the sensitivity of snow surface HONO concentrations to the model parameters. It is clear that the model results are quite sensitive to the volume exclusion factor and the $\mathrm{pH}$ and nitrite concentration in the surface layer. It also implies that the snowpack can be a HONO sink if snowpack nitrite concentrations are low.

It should also be kept in mind that the use of Henry's Law for gas-liquid partitioning coefficients is really only relevant to ideal solutions, which under the volume concentration effect of the "QLL" is not likely. How to correct for nonideality in the "QLL" is not clear, however, as the actual solute concentrations and the partitioning at low temperatures are not known. Other reactions can happen, for example, $\mathrm{NO}_{2}^{-}$and $\mathrm{HONO}$ can be oxidized by molecular oxygen to nitrate ions at a much faster rate (Takenaka et al., 1992, 1996). However, the importance of these reactions remains unexplored. 


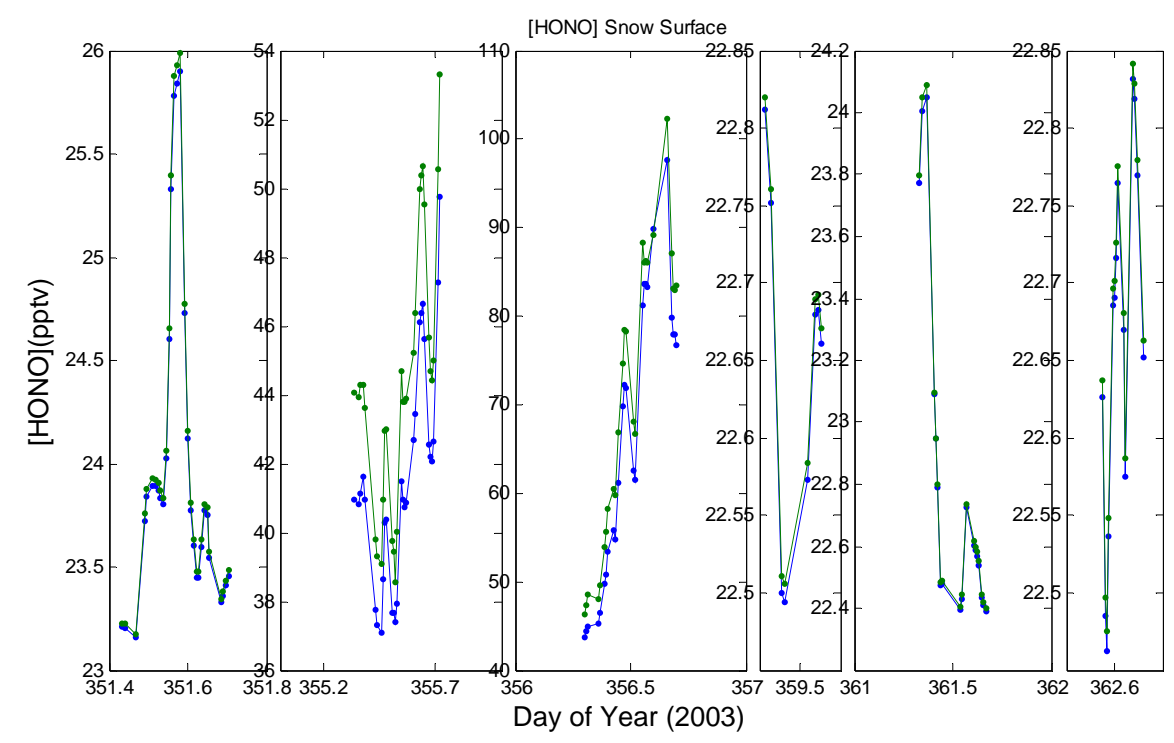

Fig. 7. Comparison of snowpack surface $[\mathrm{HONO}]$ with doubled $\left[\mathrm{NO}_{3}^{-}\right]$(green line) and and base model $\left[\mathrm{NO}_{3}^{-}\right]($blue line).

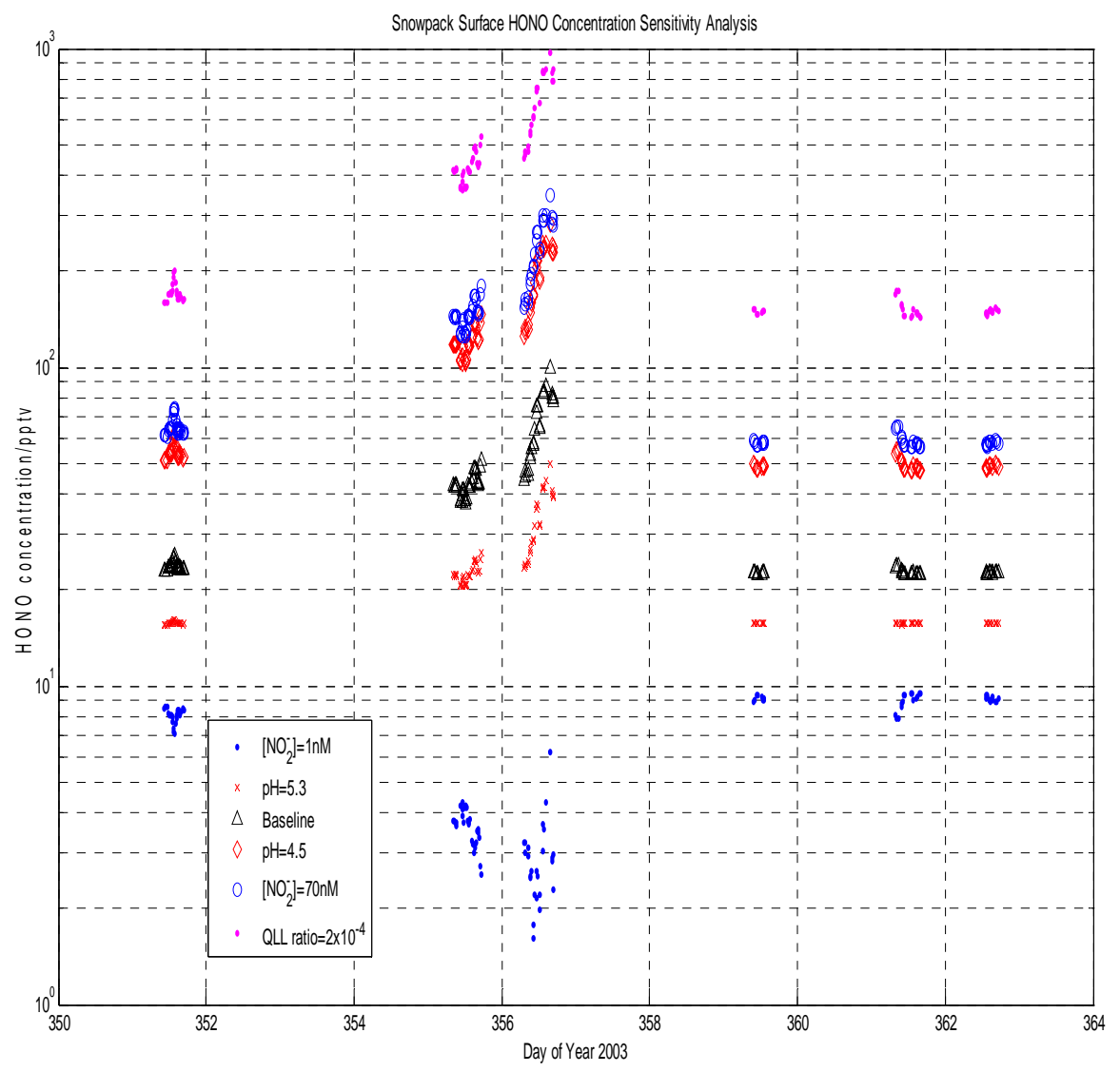

Fig. 8. Sensitivity analysis of HONO concentration at the snow surface. 


\section{Conclusion and discussion}

The model presented here provides an integrated physicochemical treatment of HONO production from the snowpack. The 1-D model incorporates interstitial transport, inter-phase transfer and the main chemical sources and sinks inside the snowpack. The observed HONO emission from the snowpack is triggered mainly by the equilibrium between "QLL" nitrite and firn air HONO deep below the snow surface. The high concentration of HONO in the firn air is subsequently transported above the snowpack by diffusion and windpumping.

HONO is not the only photochemically important molecule thought to be produced from snowpack: others include $\mathrm{NO}_{\mathrm{x}}$, formaldehyde and other light carbonyls, and possibly peroxides. The model can be readily extended to include these other species. There are, however, a number of issues to address in order to improve the model. The lack of many observational constraints, such as surface relief, snowpack concentration profiles, snow porosity and permeability, etc., forced many assumptions and parameterizations. There are also many uncertainties involving the nature of the "QLL" and the chemistry therein. This paper pinpoints the directions for both the observational goals of future field measurements as well as laboratory studies of real-world ices.

There are sufficient uncertainties in the model to preclude high precision in the results; the hope here is to identify and to the extent possible quantify the sensitivities to the important uncertainties (Table 3). The critical sensitivities of the model involve the volume exclusion factor, in particular its magnitude and dependence on temperature and solute concentration, as this determines the snow-phase chemical concentrations and, in conjunction with ion speciation, the $\mathrm{pH}$. We emphasize that the assumptions that the "QLL" is a true liquid and that aqueous-phase reaction mechanisms are relevant require validation. Laboratory work addressing questions involving the surface layer of impure ices is greatly needed at this point. Gas-liquid partitioning data for nonideal solutions at temperatures relevant to polar conditions are also required.

As noted, the model suffers from a limited set of observational constraints from the field. For a better understanding of the role that the snowpack plays in polar and alpine photochemistry it is recommended that vertical profiles of snow permeability and porosity; actinic flux; and chemical precursor concentrations be measured in future field campaigns. Measurement of the total concentration of solvated species, ions as well as uncharged species, is important for estimating the "QLL" species concentrations. Solute speciation may also be important in determining the $\mathrm{pH}$ of the surface layer. The vertical distribution of HONO and other species emitted to the firn air is most sensitive to windpumping. More attention should be paid in future field studies to the surface relief and its orientation with respect to wind direction.
Acknowledgements. This paper would not have been possible without the assistance of many individuals. We would like to acknowledge Jack Dibb from University of New Hemisphere, who provided us with much unpublished data and constructive suggestions; Gao Chen from National Aeronautics and Space Administration (NASA), who merges the ANTCI 2003 data and provide his gas phase model results as a reference; Detlev Helmig from University of Colorado and William Neff from National Oceanic \& Atmospheric Administration (NOAA), who provided meteorology data and analysis; Julia Lee-Taylor and Sasha Madronich from National Center for Atmospheric Research (NCAR), who not only shared their actinic flux model codes but also took the time to explain the concept to us; Kenjiro Toyota from York University, whose AGU presentation inspired us to incorporate the wind pumping model component; Tao Zeng from Georgia Institute of Technology, who patiently help us through the model building; and two anonymous reviewers and the editor for their helpful comments. Funding for this project was received from the National Science Foundation award ATM 0230246.

Edited by: R. von Glasow

\section{References}

Anderson, P. S. and Neff, W. D.: Boundary layer physics over snow and ice, Atmos. Chem. Phys., 8, 3563-3582, 2008, http://www.atmos-chem-phys.net/8/3563/2008/.

Bartels-Rausch, T. and Donaldson, D. J.: $\mathrm{HONO}$ and $\mathrm{NO}_{2}$ evolution from irradiated nitrate-doped ice and frozen nitrate solutions, Atmos. Chem. Phys. Discuss., 6, 10 713-10 731, 2006, http://www.atmos-chem-phys-discuss.net/6/10713/2006/.

Beine, H. J., Amoroso, A., Esposito, G., Sparapani, R., Ianniello, A., Georgiadis, T., Nardino, M., Bonasoni, P., Cristofanelli, P., and Domine, F.: Deposition of atmospheric nitrous acid on alkaline snow surfaces, Geophys. Res. Lett., 32, L10808, doi:10.1029/2005GL022589, 2005.

Boxe, C. S.: Nitrate photochemistry and interrelated chemical phenomena in ice: influence of the quasi-liquid layer (QLL), Ph.D. thesis, California Institute of Technology, 2005.

Burley, J. D. and Johnston, H. S.: Ionic mechanisms for heterogeneous stratospheric reactions and ultraviolet photo absorption cross-sections for $\mathrm{NO}_{2}^{+}, \mathrm{HNO}_{3}$, and $\mathrm{NO}_{3}^{-}$in sulfuric-acid, Geophys. Res. Lett., 19, 1359-1362, 1992.

Chu, L. and Anastasio, C.: Quantum yields of hydroxyl radical and nitrogen dioxide from the photolysis of nitrate on ice, J. Phys. Chem. A, 107, 9594-9602, 2003.

Jones, A. E., Wolff, E. W., Ames, D., Bauguitte, S. J.-B., Clemitshaw, K. C., Fleming, Z., Mills, G. P., Saiz-Lopez, A., Salmon, R. A., Sturges, W. T., and Worton, D. R.: The multi-seasonal $\mathrm{NO}_{\mathrm{y}}$ budget in coastal Antarctica and its link with surface snow and ice core nitrate: results from the CHABLIS campaign, Atmos. Chem. Phys. Discuss., 7, 4127-4163, 2007, http://www.atmos-chem-phys-discuss.net/7/4127/2007/.

Cunningham, J. and Waddington, E. D.: Air flow and dry deposition of non-sea salt sulfate in polar firn: paleoclimatic implications. Atmos. Environ., 27A, 2943-2956, 1993.

Davis, D. D., Eisele, F., Chen, G., Crawford, J., Huey, G., Tanner, D., Slusher, D., Mauldin, L., Oncley, S., Lenschow, D., Semmer, S., Shetter, R., Lefer, B., Arimoto, R., Hogan, A., Grube, P., 
Lazzara, M., Bandy, A., Thornton, D., Berresheim, H., Bingemer, H., Hutterli, M., McConnell, J., Bales, R., Dibb, J., Buhr, M., Park, J., McMurry, P., Swanson, A., Meinardi, S., and Blake, D.: An overview of ISCAT 2000, Atmos. Environ., 38, 53635373, 2004.

Dibb, J. E., Arsenault, M., Peterson, M. C., and Honrath, R. E.: Fast nitrogen oxide photochemistry in Summit, Greenland snow, Atmos. Environ., 36, 2501-2511, 2002.

Dibb, J. E., Huey, L. G., Slusher, D. L., and Tanner, D. J.: Soluble reactive nitrogen oxides at South Pole during ISCAT 2000, Atmos. Environ., 38, 5399-5409, 2004.

Domine, F. and Shepson, P. B.: Air-snow interactions and atmospheric chemistry, Science, 297, 1506-1510, 2002.

Domine, F., Albert, M., Huthwelker, T., Jacobi, H.-W., Kokhanovsky, A. A., Lehning, M., Picard, G., and Simpson, W. R.: Snow physics as relevant to snow photochemistry, Atmos. Chem. Phys., 8, 171-208, 2008, http://www.atmos-chem-phys.net/8/171/2008/.

Dubowski, Y., Colussi, A. J., and Hoffmann, M. R.: Nitrogen dioxide release in the $302 \mathrm{~nm}$ band photolysis of spray-frozen aqueous nitrate solutions. Atmospheric implications, J. Phys. Chem. A, 105, 4928-4932, 2001.

Ervens, B., George, C., Williams, J. E., Buxton, G. V., Salmon, G. A., Bydder, M., Wilkinson, F., Denener, F., Mirabel, P., and Herrmann, H.: CAPRAM 2.4 (MODAC mechanism): An extended and condensed tropospheric aqueous phase mechanism and its application. J. Geophys. Res., 108, 4426, doi:10.1029/2002JD002202, 2003.

Grenfell, T. C. and Perovich, D. K.: Radiation absorption coefficients of polycrystalline ice from 400 to $1400 \mathrm{~nm}$, J. Geophys. Res., 86, C8, 7447-7450, 1981.

Helmig, D., Johnson, B., Oltmans, S. J., Neff, W., Eisele, F., and Davis, D. D.: Elevated Ozone in the Boundary-Layer at South Pole, Atmos. Environ., 42, 2788-2803, 2008.

Herrmann, H., Buxton, G., Salmon, A., Mirabel, P., George, C., Lelieveld, J. and Denteneer, F.: Model development for tropospheric aerosol and cloud chemistry (MODAC), Final report, No. ENV4-CT97-0388, 2000.

Honrath, R. E., Peterson, M. C., Guo, S., Dibb, J. E., Shepson, P. B., and Campbell, B.: Evidence of $\mathrm{NO}_{\mathrm{x}}$ production within or upon ice particles in the Greenland snow pack, Geophys. Res. Lett., 26, 6, 695-698, 1999.

Honrath, R. E., Peterson, M. C., Dziobak, M. P., Dibb, J. E., Arsenault, M. A., and Green, S. A.: Release of $\mathrm{NO}_{\mathrm{x}}$ from sunlightirradiated midlatitude snow. Geophys. Res. Lett., 27, 15, $2237-$ 2240, 2000

Honrath, R. E., Lu, Y., Peterson, M. C., Dibb, J. E., Arsenault, M. A., Cullen, N. J., and Steffen, K.: Vertical fluxes of $\mathrm{NO}_{\mathrm{x}}$, HONO, and $\mathrm{HNO}_{3}$ above the snowpack at Summit, Greenland, Atmos. Environ., 36, 2629-2640, 2002.

Hutterli, M. A., Rothlisberger, R., and Bales, R. C.: Atmosphereto-snow-to-firn transfer studies of HCHO at Summit, Greenland, Geophys. Res. Lett., 26, 12, 1691-1694, 1999.

Jacobi, H. W., Bales, R. C., Honrath, R. E., Peterson, M. C., Dibb., J. E., Swanson, A. L., and Albert., M. R.: Reactive trace gases measured in the interstitial air of surface snow at Summit, Greenland, Atmos. Environ., 38, 1687-1697, 2004.

Joseph, J. H., Wiscombe, W. J., and Weinman, J. A.: DeltaEddington approximation for radiative flux-transfer, J. Atmos.
Sci., 33, 2452-2459, 1976.

Lee-Taylor, J. and Madronich, S.: Calculation of actinic fluxes with a coupled atmosphere-snow radiative transfer model, J. Geophys. Res.-Atmos., 107, 4796, doi:10.1029/2002JD002084, 2002.

Li, S. M.: Equilibrium of particle nitrite with gas phase HONO: Tropospheric measurements in the high Arctic during polar sunrise, J. Geophys. Res., 99, 25469-25478, 1994.

Liao, W., Case, A. T., Mastromarino, J., Tan, D., and Dibb, J. E.: Observations of HONO by laser-induced fluorescence at the South Pole during ANTCI 2003, Geophys. Res. Lett., 33, L09810, doi:10.1029/2005GL025470, 2006.

Madronich, S. and Flocke, S.: The role of solar radiation in atmospheric chemistry, in: Handbook of Environmental Chemistry, edited by: Boule, P., Springer, Heidelberg, 1-26, 1998.

McConnell, J. R., Bales, R. C., Stewart, R. W., Thompson., A. M., Albert, M. R., and Ramos, R.: Physically based modeling of atmosphere-to-snow-to-firn transfer of $\mathrm{H}_{2} \mathrm{O}_{2}$ at South Pole. J. Geophys. Res., 103, D9, 10 561-10 570, 1998.

Michalowski, B. A., Francisco, J. S., Li, S. M., Barrie, L. A., Bottenheim, J. W., and Shepson, P. B.: A computer model study of multiphase chemistry in the Arctic boundary layer during polar sunrise, J. Geophys. Res.-Atmos., 105, 15 131-15 145, 2000.

Neuweiler, I., Attinger, S., and Kinzelbach, W.: Macrodispersion in a radially diverging flow field with finite Peclet numbers 1 . Pertubation theory approach, Water Resour. Res., 37, 481-493, 2001.

Park, J.-Y. and Lee, Y.-N.: Solubility and decomposition kinetics of nitrous acid in aqueous solution, J. Phys. Chem., 92, 6294-6302, 1988.

Perovich, D. K. and Govoni, J. W.: Absorption coefficients of ice from 250 to $400 \mathrm{~nm}$, Geophys. Res. Lett., 18, 7, 1233-1235, 1991.

Reid, R. C., Prausnitz, J. M., and Poling, B. E.: The properties of gases and liquids, McGraw-Hill, New York, 581-582, 1987.

Riordan, E., Minogue, N., Healy, D., O'Driscoll, P., and Sodeau, J. R.: Spectroscopic and optimization modeling study of nitrous acid in aqueous solution. J. Phys. Chem. A, 109, 5, 779-786, 2005.

Sander, S. P., Friedl, R. R., Golden, D. M., Kurylo, M. J., Moortgat, G. K., Wine, P. H., Ravishankara, A. R., Kolb, C. E., Molina, M. J., Finlayson-Pitts, B. J., Huie, R. E., and Orkin, V. L.: Chemical Kinetics and Photochemical Data for Use in Atmospheric Studies, Eval. 15, National Aeronautics and Space Administration, Jet Propulsion Laboratory, and California Institute of Technology, Pasadena, CA, 2006.

Schwartz, S. E.: Mass transport considerations pertinent to aqueous phase reactions of gases in liquid water clouds, in: Chemistry of Multiphase Atmospheric Systems, edited by: Jaeschke, W., NATO ASI Series, Vol. 6, Springer, Berlin, 415-471, 1986.

Sportisse, B. and Djouad, R.: Some aspects of multi-time scale issues for the numerical modeling of atmospheric chemistry. Atmospheric Modeling. Series: The IMA Volumes in Mathematics and its Applications, 130, 39-59, Springer, New York, 2000.

Takenaka, N., Uede, A., and Maeda, Y.: Acceleration of the rate of nitrite oxidation by freezing in aqueous solution, Nature, 358, 736-738, 1992.

Takenaka, N., Uede, A., Daimon, T., Bandow, H., Dohmaru, T., and Maeda, Y.: Acceleration mechanism of chemical reaction by freezing: The reaction of nitrous acid with dissolved oxygen, J. 
Phys. Chem., 100, 13 874-13 884,1996.

Toon, O. B., Mckay, C. P., Ackerman, T. P., and Santhanam, K.: Rapid calculation of radiative heating rates and photodissociation rates in inhomogeneous multiple-scattering atmospheres, J. Geophys. Res.-Atmos., 94, 16 287-16301, 1898.

Toyota, K. and McConnell, J. C.: One-dimensional modeling of airsnowpack interactions and bromine activation in the springtime Arctic air, oral presentation at 2005 AGU Fall Meeting, abstract \#A13F-07, San Francisco, CA, USA, 5-9 December, 2005.

Waddington, E. D., Cunningham, J., and Harder, S. L.: The effects of snow ventilation on chemical concentrations, in: Chemical Exchange Between the Atmosphere and Polar Snow, edited by: Wolff, E. W. and Bales, R. C., NATO ASI Series I, Global Environmental Change, Vol. 43, Springer Verlag, Berlin, 403-451, 1996.

Waldner, P. A., Schneebeli., M., Schultze-Zimmermann, U., and Fluhler, H.: Effect of snow 15 structure on water flow and solute transport, Hydrol. Process., 18, 1271-1290, 2004.

Warneck, P. and Wurzinger, C.: Product quantum yields for the 305$\mathrm{nm}$ photodecomposition of $\mathrm{NO}_{3}^{-}$in aqueous-solution, J. Phys. Chem., 92, 6278-6283, 1988.
Warren, S. G., Brandt, R. E., and Hinton, R. O'R: Effect of surface roughness on bidirectional reflectance of Antarctic snow, J. Geophys. Res., 103, 25 789-25 807, 1998.

Yang, J., Honrath, R. E., Peterson, M. C., Dibb, J. E., Sumner, A. L., Shepson, P. B., Frey, M., Jacobi, H.-W., Swanson, A., and Blake, N.: Impact of snow pack photochemistry on $\mathrm{HO}_{\mathrm{x}}$ levels at Summit, Greenland, Atmos. Environ., 36, 2523-2534, 2002.

Zellner, R., Exner, M., and Herrmann, H.: Absolute OH quantum yields in the laser photolysis of nitrate, nitrite and dissolved $\mathrm{H}_{2} \mathrm{O}_{2}$ at 308 and $351 \mathrm{~nm}$ in the temperature-range $278-353 \mathrm{~K}, \mathrm{~J}$. Atmos. Chem., 10, 411-425, 1990.

Zhou, X., Beine, H. J., Honrath, R. E., Fuentes, J. D., Simpson, W., Shepson, P. B., and Bottenheim, J. W.: Snow pack photochemical production of HONO: A major source of $\mathrm{OH}$ in the Arctic boundary layer in springtime, Geophys. Res. Lett., 28, 40874090, 2001. 